\title{
Enhanced enteric invasion of scrapie agents into the villous columnar epithelium via maternal immunoglobulin
}

\author{
YASUHISA ANO ${ }^{1,2}$, AKIKAZU SAKUDO ${ }^{3}$, RYUTA URAKI $^{1}$, YUKITA SATO ${ }^{4}$, JYURI KONO $^{4}$, \\ KATSUAKI SUGIURA ${ }^{5}$, TAKASHI YOKOYAMA ${ }^{6}$, SHIGEYOSHI ITOHARA ${ }^{7}$, \\ HIROYUKI NAKAYAMA $^{1}$, MASAYOSHI YUKAWA ${ }^{4}$ and TAKASHI ONODERA ${ }^{1}$ \\ ${ }^{1}$ Graduate School of Agricultural and Life Sciences, The University of Tokyo, 1-1-1 Yayoi, Bunkyo-ku, Tokyo 113-8657; \\ ${ }^{2}$ Central Laboratories for Frontier Technology, Kirin Holdings Co., Ltd., 1-13-5 Fukuura Kanazawa-ku, Yokohama, \\ Kanagawa 236-0004; ${ }^{3}$ Research Institute for Microbial Diseases, Osaka University, Yamadaoka, Suita, \\ Osaka 565-0871; ${ }^{4}$ Department of Veterinary Medicine, College of Biosource Sciences, Nihon University, \\ Kameino 1866, Fujisawa, Kanagawa 252-8510; ${ }^{5}$ Food and Agricultural Materials Inspection Centre, \\ Saitama 330-9731; ${ }^{6}$ Prion Disease Research Center, National Institute of Animal Health, Ibaraki 305-0856; \\ ${ }^{7}$ Laboratory for Behavioral Genetics, Brain Science Institute, RIKEN, Wako, Saitama 351-0198, Japan
}

Received June 22, 2010; Accepted July 31, 2010

DOI: 10.3892/ijmm_00000533

\begin{abstract}
Transmissible spongiform encephalopathies (TSE) are caused by dietary oral exposure to infectious prion proteins $\left(\mathrm{PrP}^{\mathrm{Sc}}\right)$; however, the mechanism behind the uptake of $\mathrm{PrPSc}^{\mathrm{Sc}}$ in the intestines is poorly understood. In addition, epidemiological studies of BSE showed that most cattle are exposed to the agents in the first 6 months of life, during the suckling and weaning periods. In the present study, to elucidate the enteric invasion mechanism of prions and to investigate the age-dependent transmission mechanism suggested by epidemiological studies, wild-type and SCID mice were orally administered brain homogenate from scrapie (Tsukuba 1)-infected mice during the suckling and weaning stages, before being analyzed histopathologically. $\operatorname{PrPSc}^{\mathrm{Sc}}$ was found to be incorporated into the villous columnar epithelial cells and was also detected in the villous lacteal of 15-day-old suckling mice. However, no such uptake of $\mathrm{PrPsc}^{\mathrm{sc}}$ was observed in the weaned mice at 25-days-old. Four different strains of mice were tested. There was no mouse strain difference in the frequency of $\mathrm{PrP}^{\mathrm{Sc}}$ positive columnar epithelial cells. In addition, the uptake of $\mathrm{PrP}^{\mathrm{Sc}}$ in suckling SCID mice lacking maternal antibodies was significantly lower than that in the wild-type suckling mice, and the uptake of $\mathrm{PrP}^{\mathrm{Sc}}$ was enhanced
\end{abstract}

Correspondence to: Professor Takashi Onodera, Department of Molecular Immunology, Graduate School of Agricultural and Life Sciences, The University of Tokyo, Bunkyo-ku, Tokyo 113-8657, Japan

E-mail: aonoder@mail.ecc.u-tokyo.ac.jp

Key words: columnar epithelial cells, maternal immunoglobulin, prion protein, SCID mice, scrapie, suckling period by dilution with purified IgG. In the present study, it was suggested that the weaning period and maternal immunoglobulin are important risk factors for the oral transmission of $\mathrm{PrP}^{\mathrm{Sc}}$.

\section{Introduction}

Transmissible spongiform encephalopathies (TSE) are a group of fatal neurodegenerative diseases characterized by the abundant accumulation of abnormal prion proteins $\left(\mathrm{PrP}^{\mathrm{Sc}}\right)$ with $B$-sheet structures $\left(\mathrm{PrP}^{\mathrm{Sc}}\right)$ (1). The most probable entry site of $\operatorname{PrP}^{\mathrm{Sc}}$ is the intestinal tract. After entry, the transmissible agents pass through one or several biological barriers and finally reach the brain (2). The peroral route of entry is widely assumed to be the most important in the natural pathogenesis of bovine spongiform encephalopathy (BSE), scrapie (3), variant Creutzfeldt-Jakob disease (vCJD) (4) and other TSE (5). Such transmission has also been shown to be caused by dietary exposure to $\mathrm{PrP}^{\mathrm{Sc}}$-contaminated food; however, the uptake process and the movement of infectious agents from the intestines to the central nervous system (CNS) are poorly understood.

Experimental models of the oral transmission of BSE agent in mink $(6)$, mice $(7)$, sheep $(8,9)$ and non-human primates $(10,11)$ and experimental models of the oral transmission of scrapie agent in hamsters $(12,13)$ and mice $(14)$ have been established. These models focused on the accumulation of $\mathrm{PrP}^{\mathrm{Sc}}$ in gut-associated lymphoid tissue (GALT) and the neuroinvasion of $\mathrm{PrP}^{\mathrm{Sc}}$ into the peripheral nervous system. Invasion through the intestinal epithelial barrier is the first critical step in oral transmission, but the mechanism of intestinal epithelial invasion by $\mathrm{PrP}^{\mathrm{Sc}}$ is poorly understood.

$\mathrm{PrP}^{\mathrm{Sc}}$ was shown to accumulate around the follicular dendritic cells (FDC) of GALT and in tangible-body macrophages of lymphoid nodules (15). $\mathrm{PrP}^{\mathrm{Sc}}$-positive cells with the morphology of dendritic cells and macrophages were also found to be scattered throughout the dome region of intestinal 
Peyer's patches (16). This suggests that M cells in the follicleassociated epithelium are the entry site of transmissible agents (17); however, no reports on the entry sites from the gut lumen or the distribution of $\mathrm{PrP}^{\mathrm{Sc}}$ in the early stage of infection have been published.

There is a report dealing with $\mathrm{PrP}^{\mathrm{Sc}}$ transport across the intestinal mucosa in sheep that had been operated on to form an intestinal loop (18) and inoculated with $\mathrm{PrP}^{\mathrm{Sc}}$ into the lumen of the loop. The report shows that trans-epithelial passage through the intact villous epithelium was more probable than that through M cells in Peyer's patches.

In addition, epidemiological studies and simulation models of BSE showed that most cattle are exposed to the agents in the first 6 months of life and that younger cattle are more likely to be infected than older cattle (19). The first 6 months of life in cattle represent the suckling and weaning periods, when the gastrointestinal tracts are still immature. During the suckling period, the intestinal epithelium easily takes up proteins such as immunoglobulins and growth factors from milk. Therefore, the intestinal epithelium may play a role in the incorporation of $\mathrm{PrP}^{\mathrm{Sc}}$ during the suckling period.

We have already demonstrated that amyloid- $\beta$ protein is incorporated into the villous epithelium during the suckling and weaning periods in mice (20) and cattle (21). In the present study, to elucidate the enteric invasion mechanism of prions and examine the age-dependent transmission mechanism suggested by previous epidemiological studies, scrapie agents were orally administered to mice during the suckling or weaning period, and then the mice were subjected to histopathological analysis.

\section{Materials and methods}

Experimental animals. Fifteen-, 20- and 25-day-old CD-1, $\mathrm{BALB} / \mathrm{c}$ and C57BL/6 mice and 15-day-old CD-1.SCID mice (Japan CLEA, Tokyo, Japan) were housed in SPF conditions under an alternating $14 \mathrm{~h} / 10 \mathrm{~h}$ light/dark cycle. The animals were given free access to standard laboratory food (Oriental Yeast Co., Ltd., Tokyo, Japan) and tap water and were treated in accordance with the procedures authorized by the Animal Experiment Committee of Nihon University College of Biosource Sciences.

Administration of $\operatorname{PrP}^{S c}$ and preparation of tissue specimens. To observe the differences in uptake between the suckling and weaning periods, mice (age, 15, 20 or 25 days; $n=3$ for each age and each administered substance) were administered with mouse brain homogenates from mice in the terminal stage of infection with mouse-adapted scrapie (Tsukuba 1 strain) (22). Ten percent brain homogenates (w/v) of scrapie infected or normal mouse brains in sterile PBS were prepared by a previously described method (23), and then 15-, 20- and 25-day-old mice were orally administered the brain homogenates. One gram of brain material was positive by Western blotting until 1:1000000 dilution. The administration was repeated $3 \mathrm{~h}$ later, and at $1 \mathrm{~h}$ post-administration (p.a.) the mice were euthanized with ether. The administered amount for the 15-day-old mice was $100 \mu 1$ and those of the 20- and 25-day-old mice were determined in proportion to the weight of each mouse. Next, to elucidate the involvement of maternal immunoglobulin in the intestinal invasion of scrapie agents, 15-day-old suckling SCID mice were administered $100 \mu \mathrm{l}$ of $10 \%$ homogenate $(\mathrm{w} / \mathrm{v})$ composed of scrapie-infected brains diluted with PBS $(\mathrm{n}=5)$ or diluted with PBS containing $5 \mathrm{mg} /$ $\mathrm{ml}$ purified mouse IgG (Beckman, Fullerton, CA, USA, n=3) or normal mouse brains diluted with PBS $(n=3)$. The administration was repeated $3 \mathrm{~h}$ later, and at $1 \mathrm{~h}$ post-administration (p.a.) the mice were euthanized with ether. Their intestines were then removed and fixed by immersion in PBS containing $4 \%$ paraformaldehyde for $2 \mathrm{~h}$ before being washed in PBS containing $6.8 \%$ sucrose. After dehydration in $100 \%$ acetone for $1 \mathrm{~h}$, tissue samples were embedded in resin (Technovit 8100; Heraeus Kulzer, Wehrheim, Germany) in accordance with the manufacturer's instructions and sectioned at a thickness of $4 \mu \mathrm{m}$.

Identification of $\mathrm{PrP}^{\mathrm{Sc}}$. $\mathrm{PrP}^{\mathrm{Sc}}$-deposition in the brains of mice at the terminal stage of Tsukuba 1 infection was confirmed using rabbit anti-PrP polyclonal antibody (P8, 1:100), (24) and mouse anti-PrP monoclonal antibody (T2, $10 \mu \mathrm{g} / \mathrm{ml}),(25)$ using a conventional immunohistochemical procedure (26). The $\mathrm{PrP}^{\mathrm{Sc}}$ in the intestines was identified by immunohistochemistry. Resin sections obtained from mice treated with $\mathrm{PrP}^{\mathrm{Sc}}$ were pretreated with $0.1 \% \mathrm{CaCl}_{2}$ at $\mathrm{pH} 7.8$ containing $0.01 \%$ trypsin for $10 \mathrm{~min}$ at $37^{\circ} \mathrm{C}$ and were then quenched in $0.3 \%$ hydrogen peroxide in methanol for $30 \mathrm{~min}$. After incubation with rabbit anti-PrP polyclonal antibody (P8, 1:100) or mouse anti-PrP monoclonal antibody (T2, $10 \mu \mathrm{g} /$ $\mathrm{ml}$ ) at $37^{\circ} \mathrm{C}$ for $2 \mathrm{~h}$ and secondary horseradish peroxidasecoupled goat anti-rabbit IgG antibody or goat anti-mouse IgG antibody (4 $\mu \mathrm{g} / \mathrm{ml}$; Nichirei, Tokyo, Japan), respectively, at room temperature for $30 \mathrm{~min}$, diaminobenzidine (DAB; Wako, Osaka, Japan) was applied for $10 \mathrm{~min}$. The sections were then counterstained with hematoxylin for $1 \mathrm{~min}$. The number of $\mathrm{PrP}^{\mathrm{Sc}}$ positive cells in each microscope-visual field in the villous epithelium was counted at five random points. Cell counts were expressed as the mean \pm SD of the microscopic fields viewed at $\times 400$ magnification. Intestinal epithelial cells were selected for determining the intensity of infection, which was not known to the observer measuring the respective intestinal sections. Statistical analysis $(\mathrm{P}<0.01)$ was performed to assess the differences between groups using the Student's t-test.

Lectin staining to identify the targeted cells. To analyze the $\mathrm{PrP}^{\mathrm{Sc}}$ positive cells, the resin-fixed sections were treated with PBS containing 1\% BSA for $30 \mathrm{~min}$. Then, they were incubated with rabbit anti-PrP polyclonal antibody (P8, 1:100) for $2 \mathrm{~h}$ at $37^{\circ} \mathrm{C}$ and secondary Alexa Fluor ${ }^{\circledR}$ 546-coupled goat anti-rabbit IgG antibody $(5 \mu \mathrm{g} / \mathrm{ml}$ Molecular Probes, Eugene, OR, USA). Ulex europaeus agglutinin (UEA-1) conjugated to rhodamine (Vector Labs, Burlingame, CA, USA) and wheat germ agglutinin (WGA) conjugated to Alexa Fluor ${ }^{\circledR} 350$ (Molecular Probes) were used. The sections were incubated at room temperature for $1 \mathrm{~h}$ with the lectins $(10 \mu \mathrm{g} / \mathrm{ml})$.

\section{Results}

Detection of $P r P^{S c}$ using two anti-PrP antibodies. Scrapie agents of the Tsukuba 1 strain were successfully detected 

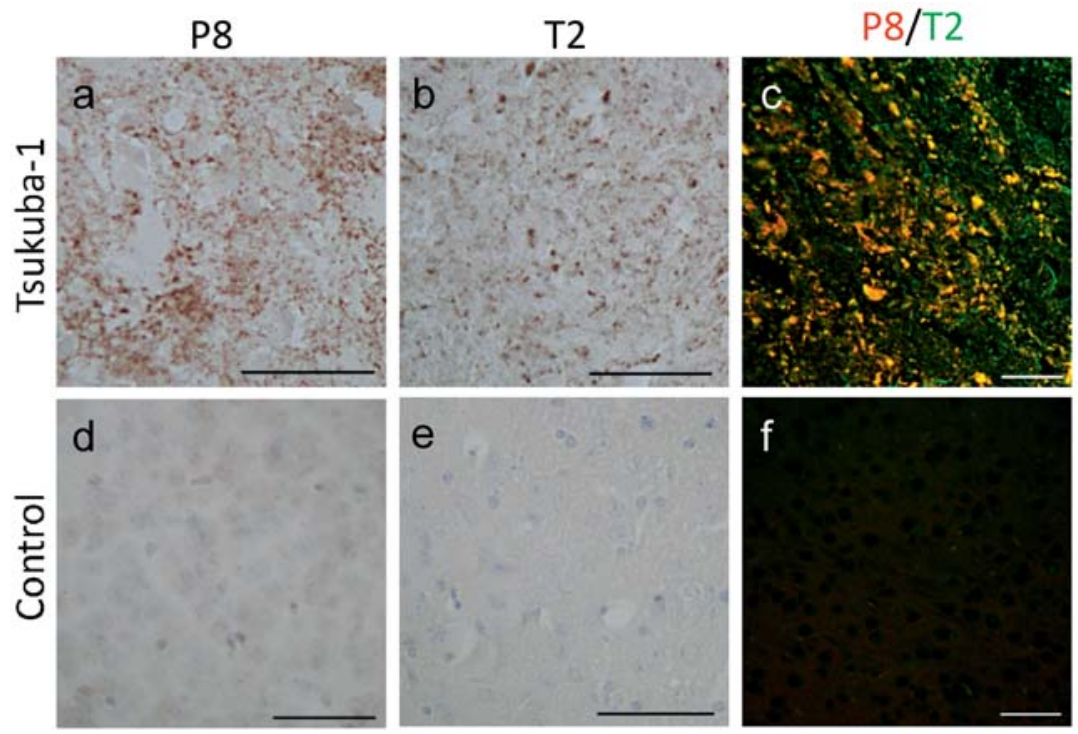

Figure 1. Detection of PrP ${ }^{\mathrm{Sc}}$ by two anti-PrP antibodies. Mouse brains from CD-1 mice at the terminal stage of infection with scrapie prion [Tsukuba 1 strain, (a-c)] and normal CD-1 mouse brains (d-f). $\operatorname{PrP}^{\mathrm{Sc}}$ was detected by immunohistochemistry using rabbit anti-PrP polyclonal antibody [P8, (a, d)] and mouse anti-PrP monoclonal antibody [T2, (b, e)], as well by an immunofluorescent assay using P8 (red) and T2 (green) antibodies. PrPs ${ }^{\mathrm{Sc}}$ was detected (a, b), and the same $\mathrm{PrP}^{\mathrm{Sc}}$ was identified by both antibodies (c).

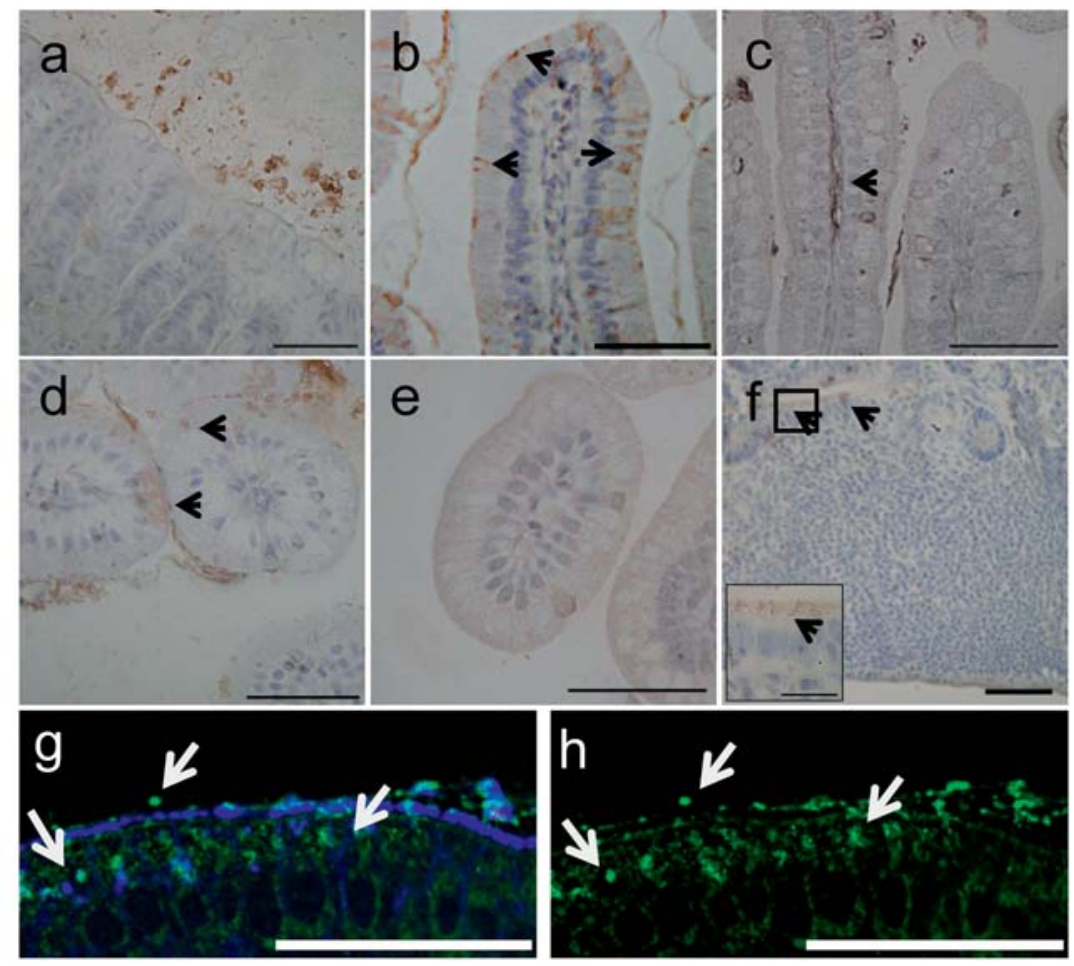

Figure 2. Uptake of $\mathrm{PrP}^{\mathrm{Sc}}$ through the villi. The duodenum (a), jejunum (b-e), and Peyer's patch (f) in 15-day-old CD-1 mice. The mice were orally administered the brain homogenates of scrapie (Tsukuba 1) infected mice (a-d, f) and normal mice (e). PrPsc was incorporated into the villous epithelial cells in the jejunum [arrows, (b, d)] but not into those of the duodenum (a). PrPsc was also detected in the dome epithelium of Peyer's patches (f) and in the villous lacteal (f, arrows). PrPsc was detected by P8 (b) and T2 (d) anti-prion protein antibodies, whereas no PrP was detected in the CD-1 mice administered a homogenate composed of normal CD-1 mouse brains. The lectins used were UEA-1 conjugated with rhodamine and WGA conjugated with Alexa Fluor ${ }^{\circledR} 350$. The luminal surface of the columnar epithelial cells in the villus is shown in blue $(\mathrm{g}, \mathrm{h})$. The columnar cells (arrows) took up PrPsc (green). The scale bars represent $50 \mu \mathrm{m}$ (a-f, $\mathrm{g}$ and $\mathrm{h}$ ) and $20 \mu \mathrm{m}$ (magnification of $\mathrm{f}$ ).

using rabbit anti-mouse PrP polyclonal antibody (P8, Fig. 1a) and mouse anti-PrP monoclonal antibody (T2, Fig. 1b) in the brains of CD-1 mice at the terminal stage of scrapie-infection. These two antibodies identified the same PrPsc (Fig. 1c). In the normal CD-1 mouse brains, no PrPSc was detected (Fig. 1d-f).
Incorporation through the villi. $\mathrm{PrP}^{\mathrm{Sc}}$ was detected by immunohistochemistry using both rabbit anti-PrP polyclonal antibody (P8, Fig. 2a-c) and mouse anti-PrP monoclonal antibody (T2, Fig. 2d). PrPsc was not incorporated into the villous epithelium in the duodenum (Fig. 2a) but was present 
15-day-old

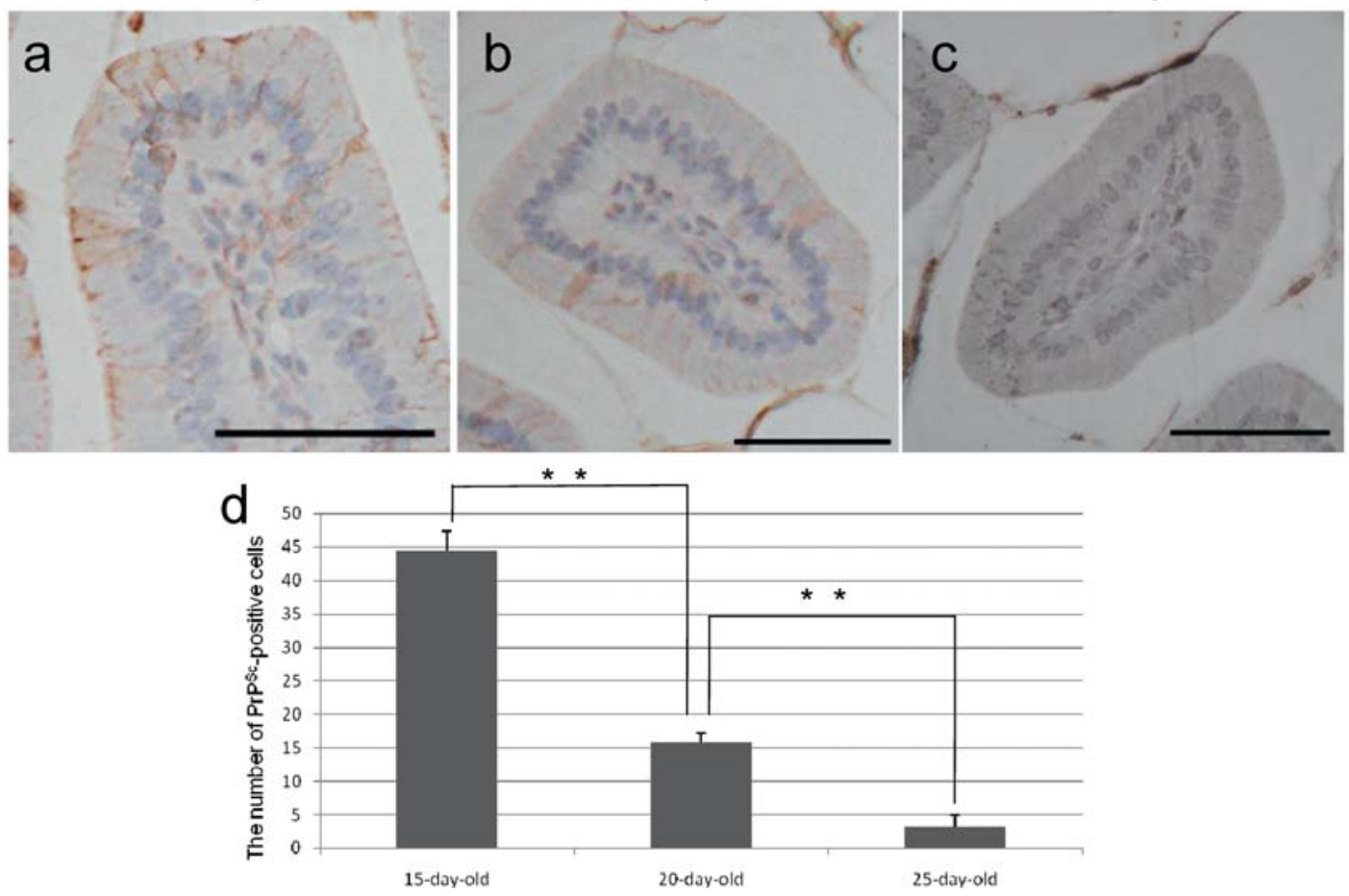

Figure 3. Age-dependent uptake of $\mathrm{PrP}^{\mathrm{Sc}}$. Intestinal villi of 15- (a), 20- (b) and 25-day-old mice (c) that had been orally administered PrPSc. PrPSc was incorporated readily into the villi of the 15 -day-old CD-1 mice, incorporated slightly in the 20-day-old CD-1 mice, but not incorporated at all in the 25-dayold CD-1 mice. The number of ileal epithelial cells that had incorporated PrPsc was significantly higher in the 15 -day-old CD-1 mice than in the 20- or 25day-old CD-1 mice (d). The results are expressed as the mean \pm SD. The statistical significance of differences was determined by the Student's t-test. ${ }^{* *} \mathrm{P}<0.01$. Scale bar, $50 \mu \mathrm{m}$.

in the jejunum (Fig. 2b and d, arrows) of 15-day-old CD-1 mice and was also detected in the villous lacteal (Fig. 2c, arrow). On the other hand, PrP was not detected in the CD-1 mice orally administered the homogenate of normal mice brains (Fig. 2e). In addition, the sections that were only reacted with the secondary antibodies did not show $\operatorname{PrP}^{\mathrm{Sc}}$ on immunohistochemistry. In the Peyer's patches, some PrPsc was detected in the dome epithelium (Fig. 2f, arrows) but none was found in the subepithelial dome or germinal center regions.

Incorporation across absorptive epithelial cells. Four kinds of cells were identified in the intestinal villous epithelium of the 15-day-old CD-1 mice: UEA-1-positive and WGAnegative (UEA-1+/WGA-), UEA-1-positive and WGA-positive (UEA-1+/ WGA $^{+}$), UEA-1-negative and WGA-positive (UEA-1-/WGA ${ }^{+}$), and UEA-1-negative and WGA-negative (UEA-1//WGA') cells (data not shown). $\mathrm{PrP}^{\mathrm{Sc}}$ was detected in the UEA-1//WGA ${ }^{+}$cells (Fig. $2 \mathrm{~g}$ and $\mathrm{h}$ ).

Age-dependent incorporation. To determine whether aged mice were less reactive to scrapie agent ingestion, intestinal sections were observed using immunohistochemistry. $\mathrm{PrP}^{\mathrm{Sc}}$ was incorporated into the villous epithelium and the lamina propria in the 15-day-old CD-1 mice (Fig. 3a). On the other hand, $\operatorname{PrP}^{\mathrm{Sc}}$ was attached to the luminal surface of villous epithelial cells but was scarcely detected in the villous columnar epithelial cells in the 20-day-old CD-1 mice (Fig. 3b) and was not found at all in the 25-day-old CD-1 mice (Fig. 3c). Significantly more $\mathrm{PrPsc}^{\mathrm{Sc}}$ was incorporated into the villous epithelium in the 15-day-old CD-1 mice than in the 20-dayold CD-1 mice and in the 20-day-old CD-1 mice compared with the 25-day-old CD-1 mice (Fig. 3d).

The same experiments were repeated in $\mathrm{BALB} / \mathrm{c}$ and $\mathrm{C} 57 \mathrm{BL} / \mathrm{c}$ mice to see if there were any mouse strain differences in the intestinal incorporation of $\mathrm{PrP}^{\mathrm{Sc}}$. As shown in Fig. 4, more $\mathrm{PrP}^{\mathrm{Sc}}$ was incorporated into the villous epithelium in the 15-day-old BALB/c and C57BL/6 mice than in the 20day-old BALB/c and C57BL/6 mice (Fig. 4b and c, respectively). More $\operatorname{PrP}^{\mathrm{Sc}}$ was observed in the villous epithelium in the 20-day-old BALB/c and C57BL/6 mice than in the 25day-old BALB/c and C57BL/c mice. There were no distinct mouse strain differences in the ratio of $\mathrm{PrP}^{\mathrm{Sc}}$ incorporation among the CD-1 (Fig. 4a), BALB/c (Fig. 4b) and C57BL/6 (Fig. 4c) mice.

Differences in PrPSc uptake between suckling wild-type and SCID mice. To determine whether immunodeficient mice were less reactive to scrapie agent ingestion, intestinal sections from CD-1.SCID mice were observed using immunohistochemistry. $\mathrm{PrP}^{\mathrm{Sc}}$ uptake into the villous epithelial cells was observed in the CD-1.SCID mice (Fig. 5b). Compared with the wild-type CD-1 mice (Fig. 5a), the number of cells incorporating $\mathrm{PrPSc}^{\mathrm{Sc}}$ in the $\mathrm{CD}$-1.SCID mice was significantly lower (Fig. 5e). In the Peyer's patches, $\mathrm{PrP}^{\mathrm{Sc}}$ was incorporated into the dome epithelial cells (Fig. 5d). 

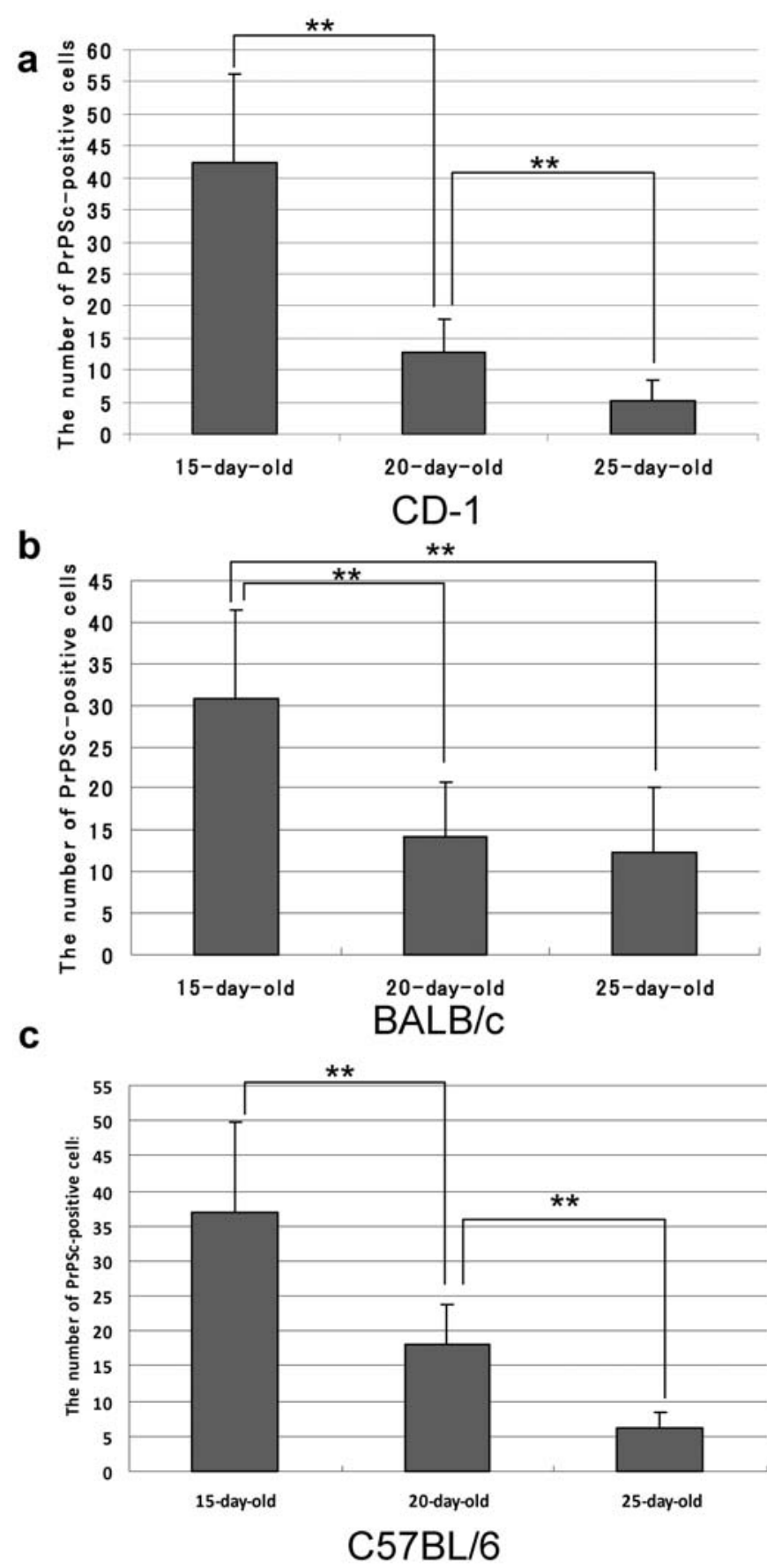

Figure 4. Age-dependent uptake of PrPsc in CD-1, BALB/c and C57BL/6 mice. $\operatorname{PrPSc}$ was incorporated readily into the villi of the 15-day-old mice, incorporated slightly in the 20-day-old mice, but not incorporated at all in the 25-day-old mice [CD-1, (a); BALB/c, (b); C57BL/6, (c)]. The number of ileal epithelial cells that incorporated $\operatorname{PrP}^{\mathrm{Sc}}$ was significantly higher in the 15-day-old mice than in the 20- or 25-day-old mice. The results are expressed as the mean $\pm \mathrm{SD}$. The statistical significance of differences was determined by the Student's t-test. ${ }^{* *} \mathrm{P}<0.01$. Scale bar, $50 \mu \mathrm{m}$.

On the contrary, the $\mathrm{PrPs}^{\mathrm{Sc}}$ uptake into the villi in the CD-1.SCID mice administered PrPsc containing abundant mouse IgG (Fig. 5c) was enhanced compared with that in CD-1.SCID mice administered only $\operatorname{PrP}^{\mathrm{Sc}}$ (Fig. 5b). As a control, mouse IgG was given orally to mice without $\mathrm{PrP}^{\mathrm{Sc}}$. Mouse intestinal sections were stained for $\mathrm{PrP}^{\mathrm{Sc}}$ using antiPrP polyclonal rabbit antibody (P8) and secondary stained with anti-rabbit $\operatorname{IgG}$ by conventional immunohistochemistry (26). In these sections, $\operatorname{PrPSc}^{\mathrm{Sc}}$ was not detected using anti-PrP polyclonal antibody and no cross-reactive staining was observed for the ingested mouse IgG using anti-rabbit IgG polyclonal secondary antibody (Fig. 5f).

\section{Discussion}

$\mathrm{PrP}^{\mathrm{Sc}}$ was detected after being incorporated by villous epithelial cells. $\mathrm{PrP}^{\mathrm{Sc}}$ is resistant to degradation by gastric juices and intestinal enzymes because of its abundant stable $\beta$-sheet structure. It was revealed previously that murine and bovine ß-amyloid proteins, which also contain many $ß$-sheet structures, were incorporated into villous columnar epithelial cells in mice (20) and cows (21). These proteins are able to resist digestion by gastric juices and intestinal enzymes in a similar manner to amyloid proteins such as $\mathrm{PrP}^{\mathrm{Sc}}$ and are incorporated into the villous epithelial cells by a common mechanism.

Villous epithelial cells are composed of absorptive, goblet, endocrine, basal granular and Paneth cells (27). Among the murine intestinal epithelial cells, the UEA- $1^{+} / \mathrm{WGA}^{-}, \mathrm{UEA}-1^{+} /$ $\mathrm{WGA}^{+}, \mathrm{UEA}^{-1}-\mathrm{WGA}^{+}$and UEA-1//WGA- cells correspond to the M, goblet, columnar, and other cells (e.g., endocrine cells), respectively (28). The villous epithelium of 15-day-old suckling mice is composed of columnar, goblet and other types of cells. The dome epithelium in Peyer's patches mainly consists of $\mathrm{M}$ cells. In the present experiment, $\operatorname{PrP}^{\mathrm{Sc}}$ was incorporated mainly through villous columnar cells, which play a primary role in nutritional absorption, rather than through $\mathrm{M}$ cells, which are responsible for the uptake of foreign substances (29). PrPSc was thought to be selectively taken up by the M cells of Peyer's patches (30), although the possibility of the incorporation of $\mathrm{PrP}^{\mathrm{Sc}}$ across columnar epithelial cells was reported recently (8). In addition, it was shown that amyloid proteins were incorporated via columnar epithelial cells in mice (20) and cows (21). This possibility was strongly supported by the present finding of the incorporation of $\mathrm{PrP}^{\mathrm{Sc}}$ via villous columnar epithelial cells.

In cases of oral or intragastric challenge with scrapie agents in hamsters, it is thought that the infectious agent first accumulates in Peyer's patches (31). These observations suggest that uptake is mediated through $\mathrm{M}$ cells in the dome epithelium of Peyer's patches. In the Peyer's patches in the present study, some $\mathrm{PrP}^{\mathrm{Sc}}$ was detected in the dome epithelium, but most was incorporated in the villous epithelium. In addition, during the suckling and weaning periods, the Peyer's patches have not fully developed. So, it was suggested that uptake through the villi is important for the intestinal epithelial invasion of $\mathrm{PrP}^{\mathrm{Sc}}$. $\mathrm{PrP}^{\mathrm{Sc}}$ was also detected in the villous lacteal, but no $\mathrm{PrPsc}^{\mathrm{Sc}}$ was found in the dome regions of Peyer's patches at $4 \mathrm{~h}$ p.a.; however, $\operatorname{PrP}^{\mathrm{Sc}}$ was detected in the dome regions at 7 days p.a. (31). $\mathrm{PrP}^{\mathrm{Sc}}$ might be transmitted to lymphatic tissues through lacteal circulation after being taken up into the villous epithelium and then accumulate in the dome regions of Peyer's patches during the period after suckling and weaning.

The present experiment also showed a difference in uptake between before and after weaning. The uptake of $\mathrm{PrP}^{\mathrm{Sc}}$ through the villi observed in suckling mice was not recognized in 25-day-old CD-1, BALB/c or C57BL/6 mice. 

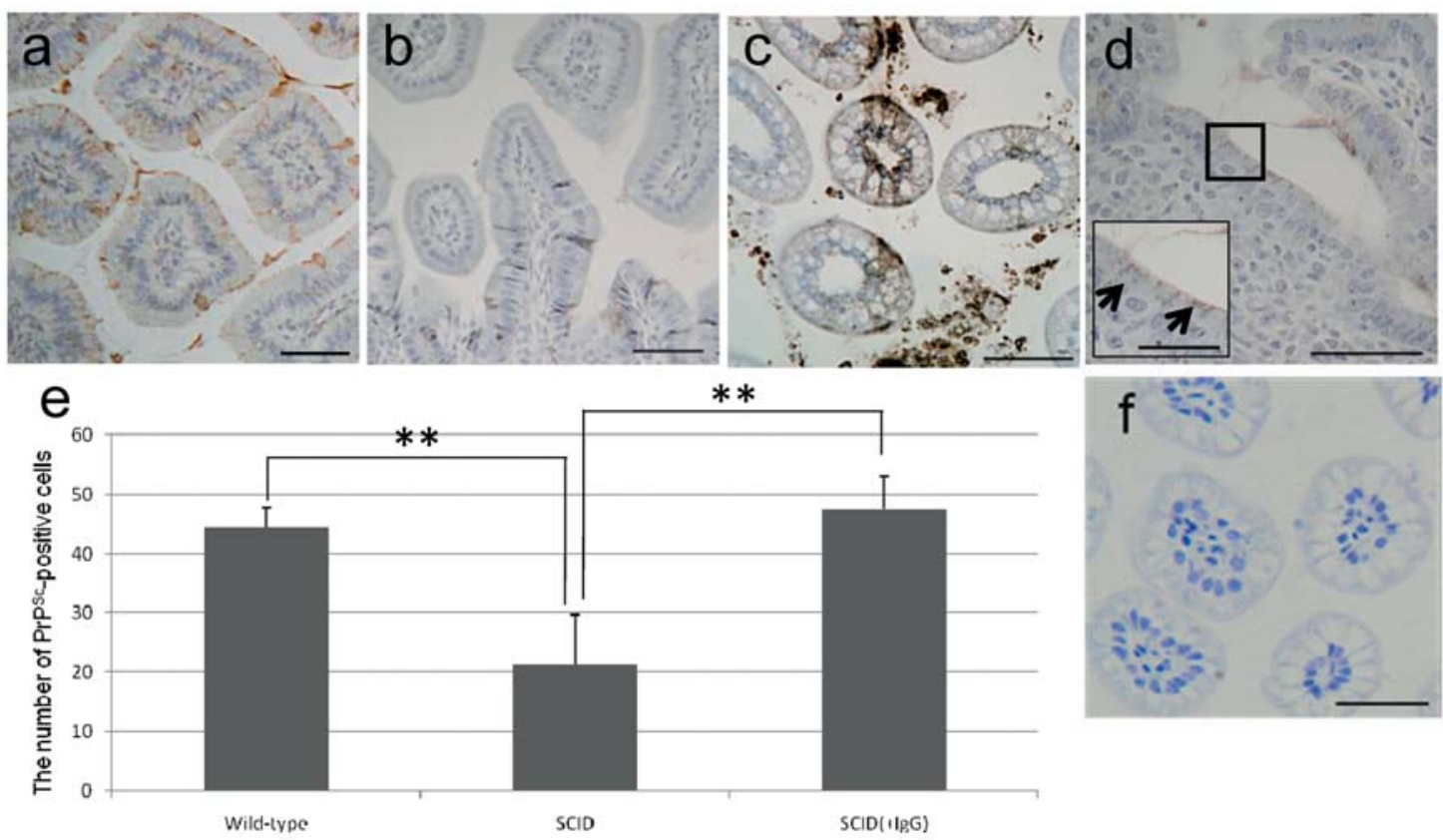

Figure 5. Uptake of PrPSc in normal and SCID mice. Intestinal villi of 15-day-old wild-type CD-1 (a) and CD-1.SCID (b, c) mice that had been orally administered PrPsc diluted with PBS (a, b) or PBS containing purified mouse IgG (c). PrPsc was incorporated into the villi of the CD-1 and CD-1.SCID mice lacking maternal antibodies. The number of ileal epithelial cells incorporating PrPsc was significantly higher in the CD-1 mice than in the CD-1.SCID mice, and the uptake was significantly enhanced by dilution with $\operatorname{IgG}(\mathrm{e})$. The statistical significance of differences was determined by the Student's t-test. ${ }^{* *} \mathrm{P}<0.01$. Scale bar, $50 \mu \mathrm{m}$. PrPSc was also detected in the dome epithelium of Peyer's patches in the CD-1.SCID mice (d). As a control, the intestinal villi of 15-day-old wild-type CD-1 mice that had been orally administered with PBS containing purified mouse IgG and immune-stained for PrPsc (f). No immune-positive cells were detected in the mice not administered $\operatorname{PrP}^{\mathrm{Sc}}$.

Proteins such as the immunoglobulins and growth factors in breast milk (32) are incorporated into the body through the villous epithelium $(33,34)$ during the suckling period without losing their original biological activity (35). Other macromolecules may also be absorbed non-specifically during the suckling period (36). In addition, during the suckling period the possibility of environmental antigenic challenge at the intestinal epithelium is lower, whereas the intestinal epithelium needs to take up more trophic and immunomodulatory factors (37). It was reported that the uptake of inert macroparticles in suckling SCID mice was significantly lower than that in normal mice (38). The neonatal Fc receptor for $\operatorname{IgG}(\mathrm{FcRn})$ binds to maternal $\operatorname{IgG}$ and is transcytosed in acidic conditions (39). In mice, FcRn is exposed on the cell surface brush border and is released at neutral $\mathrm{pH}$ on the neonatal side (40). A recent study showed that in the adult gut enterocytes transcytose $\operatorname{IgG}$ into the gut lumen where it binds to antigen. The IgG-antigen complex is then delivered to the lamina propria dendritic cells either directly or by reverse transcytosis across the epithelial T-cell barrier (40). In the present study, the levels of PrPSc incorporated by suckling SCID mice lacking maternal immunoglobulins (41) were significantly lower than those incorporated by wild-type suckling mice, whereas the uptake of $\mathrm{PrP}^{\mathrm{Sc}}$ was enhanced by immunoglobulin. So, maternal immunoglobulin plays an important role in the enteric invasion of $\mathrm{PrP}^{\mathrm{Sc}}$ into epithelial cells. It was also recently reported that the oral transmissibility of $\mathrm{PrP}^{\mathrm{Sc}}$ was enhanced by its binding to soil particles (42). In that report, it was suggested that the association of $\mathrm{PrP}^{\mathrm{Sc}}$ with soil minerals and organic carbon enhanced the oral transmissibility of prion disease relative to the unbound agent. So, it is suggested in the present study that the binding of $\operatorname{PrP}^{\mathrm{Sc}}$ to maternal immunoglobulin might enhance the enteric invasion of $\operatorname{PrP}^{\mathrm{Sc}}$ relative to unbound $\mathrm{PrP}^{\mathrm{Ps}}$. Ongoing experiments have shown that an Fc receptor blocking agent (Z- $\varepsilon$-aminocaproic acid) significantly decreased $\mathrm{PrP}^{\mathrm{Sc}}$ incorporation into the intestinal epithelia of CD-1 sucking mice. In this experiment, the incorporation of $\operatorname{IgG}$ into the intestinal epithelium was also blocked by $\mathrm{Z}-\varepsilon$-aminocaproic acid. Therefore, the addition of such blocking agents to animal feed might be useful for preventing prion infection in younger animals (data not shown).

Cows younger than 6 months old are thought to be at the highest risk of infection from dietary $\mathrm{PrP}^{\mathrm{Sc}}$ during the suckling and weaning period (19). Therefore, the villous epithelium may possess a specialized mechanism for the incorporation of foreign proteins like PrPsc during the suckling and weaning period, thereby increasing the risk of transmission across it.

The mechanism revealed in the present study using scrapie agents is a novel finding that reveals the oral transmission mechanism of prion diseases, and in particular, the mechanism by which they invade the intestinal epithelium.

\section{Acknowedgements}

This study was supported by Grant-in-Aids from the Food Safety Commission of the Japanese Government Cabinet Office and the Research Committee of Prion disease and Slow Virus Infection, the Ministry of Health, Labour and Welfare of Japan. 


\section{References}

1. Prusiner SB: Prion diseases and the BSE crisis. Science 278: 245-251, 1997

2. Ano Y, Sakudo A, Nakayama H and Onodera T: Uptake and distribution of infectious prion protein after oral exposure. Protein Peptide Lett 16: 247-255, 2009.

3. Hoinville LJ: A review of the epidemiology of scrapie in sheep. Rev Sci Tech 15: 827-852, 1996 .

4. Will RG: Acquired prion disease: iatrogenic CJD, variant CJD, kuru. Br Med Bull 66: 255-265, 2003.

5. Press CM, Heggebo R and Espenes A: Involvement of gutassociated lymphoid tissue of ruminants in the spread of transmissible spongiform encephalopathies. Adv Drug Deliv 56: 885-899, 2004

6. Robinson MM, Hadlow WJ, Huff TP, Wells GA, Dawson M, Marsh RF and Gorham JR: Experimental infection of mink with bovine spongiform encephalopathy. J Gen Virol 75: 2151-2155, 1994.

7. Gonzalez L, Terry L and Jeffrey M: Expression of prion protein in the gut of mice infected orally with the $301 \mathrm{~V}$ murine strain of the bovine spongiform encephalopathy agent. J Comp Pathol 132: 273-282, 2005.

8. Foster JD, Paruham DW, Hunter N and Bruce M: Distribution of the prion protein in sheep terminally affected with BSE following experimental oral transmission. J Gen Virol 82: 2319-2326, 2001.

9. Jeffrey M, Ryder S, Martin S, Hawkins SA, Terry L, BerthelinBaker C and Bellworthy SJ: Oral inoculation of sheep with the agent of bovine spongiform encephalopathy (BSE). 1. Onset and distribution of disease-specific $\mathrm{PrP}$ accumulation in brain and viscera. J Comp Pathol 124: 280-289, 2001

10. Bons N, Mestre-Frances N, Belli P, Cathala F, Gajdusek DC and Brown P: Natural and experimental oral infection of nonhuman primates by bovine spongiform encephalopathy agents. Proc Natl Acad Sci USA 96: 4046-4051, 1999.

11. Herzog C, Sales N, Etchegary N, Charbonnier A, Freire S, Dormont D, Deslys JP and Lasmezas CI: Tissue distribution of bovine spongiform encephalopathy agent in primates after intravenous or oral infection. Lancet 363: 422-428, 2004.

12. Prusiner SB, Cochran SP and Alpers MP: Transmission of scrapie in hamsters. J Infect Dis 152: 971-978, 1985.

13. McBride PA and Beekes M: Pathological PrP is abundant in sympathetic and sensory ganglia of hamsters fed with scrapie. Neurosci Lett 265: 135-138, 1999.

14. Maignein T, Lasmezas CI, Beringue V, Dormont D and Deslys JP: Pathogenesis of the oral route of infection of mice with scrapie and bovine spongiform encephalopathy agents. J Gen Virol 80: 3035-3042, 1999.

15. Jeffrey M, McGovern G, Goodsir CM, Brown KL and Bruce ME: Sites of prion protein accumulation in scrapie-infected mouse spleen revealed by immuno-electron microscopy. J Pathol 191: 323-332, 2000

16. Heggebo R, Press CM, Gunnes G, Lie KI, Tranulis MA, Ulvund M, Groschup MH and Landsverk T: Distribution of prion protein in the ileal Peyer's patch of scrapie-free lambs and lambs naturally and experimentally exposed to the scrapie agent. J Gen Virol 81: 2327-2337, 2000.

17. Mabbott NA and Bruce ME: Follicular dendritic cells as targets for intervention in transmissible spongiform encephalopathies. Semin Immunol 14: 285-293, 2002.

18. Jeffrey M, Gonzales L, Espenes A, et al: Transportation of prion protein across the intestinal mucosa of scrapie-susceptible and scrapie-resistant sheep. J Pathol 209: 4-14, 2006.

19. Arnold ME and Wilesmith JW: Estimation of the age-dependent risk of infection to BSE of dairy cattle in Great Britain. Prev Vet Med 66: 35-47, 2004

20. Ano Y, Nakayama H, Sakudo A, Sawano Y, Tanokura M, Itohara $\mathrm{S}$ and Onodera $\mathrm{T}$ : Intestinal uptake of amyloid $\mathrm{B}$ protein through columnar epithelial cells in suckling mice. Histol Histopathol 24: 283-292, 2009.

21. Ano Y, Nakayama H, Sakai Y, et al: Incorporation of ß-amyloid protein through the bovine ileal epithelium before and after weaning: model for orally transmitted amyloidoses. Microbiol Immunol 52: 429-434, 2008.
22. Hirogari Y, Kubo M, Kimura KM, Haritani M and Yokoyama T: Two different scrapie prions isolated in Japanese sheep flocks. Microbiol Immunol 47: 871-876, 2003.

23. Yokoyama T, Masujin K, Iwamura Y, Imamura M and Mohri S: Alteration of the biological and biochemical characteristics of bovine spongiform encephalopathy prions during interspecies transmission in transgenic mice models. J Gen Vriol 90: 261-268, 2009.

24. Inoue Y, Yamakawa Y, Sakudo A, et al: Infection routeindependent accumulation of splenic abnormal prion protein. Jpn J Infect Dis 58: 78-82, 2005.

25. Yokoyama T, Kimura KM, Ushiki Y, et al: In vivo conversion of cellular prion protein to pathogenic isoforms, as monitored by conformation-specific antibodies. J Biol Chem 276: 11265-11271, 2001.

26. Hosokawa T, Tsuchiya K, Sato I, et al: A monoclonal antibody (1D12) defines novel distribution patterns of prion protein (PrP) as granules in nucleus. Biochem Biophys Res Commun 366: 657-663, 2008.

27. Hunyady B, Mezey E and Palkovits M: Gastrointestinal immunology: cell types in the lamina propria a morphological review. Acta Physiol Hung 87: 305-328, 2002.

28. Clark MA, Jepson MA, Simmons NL, Booth TA and Hirst BH: Differential expression of lectin-binding sites defines mouse intestinal M-cells. J Histochem Cytochem 41: 1679-1687, 1993.

29. Neutra MR, Frey A and Kraehenbuhl JP: Epithelial M cells: gateways for mucosal infection and immunization. Cell 86: 345-348, 1996

30. Heppner FL, Christ AD, Klein MA, Prinz M, Fried M, Kraehenbuhl JP and Aguzzi A: Transepithelial prion transport by M cells. Nat Med 7: 976-977, 2002.

31. Beekes M and McBride PA: Early accumulation of pathological PrP in the enteric nervous system and gut-associated lymphoid tissue of hamster orally infected with scrapie. Neurosci Lett 278: 181-184, 2000.

32. Guyer RL, Koshland ME and Knopf PM: Immunoglobulin binding by mouse intestinal epithelial cell receptors. J Immunol 117: 587-593, 1976.

33. Udall JN, Colony P, Fritze L, Pang K, Trier JS and Walker WA: Development of gastrointestinal mucosal barrier: the effect of natural versus artificial feeding on intestinal permeability to macromolecules. Pediatr Res 15: 245-249, 1981.

34. Axelsson L, Jakobsson L, Lindberg T, Polberger S, Benediktsson B and Räihä N: Macromolecular absorption in preterm and term infant. Acta Paediatr Scand 78: 532-537, 1989.

35. Chu SH and Walker WA: Growth factor signal transduction in human intestinal cells. Adv Exp Med Biol 310: 107-112, 1991.

36. Teichberg S, Waprnir RA, Moyse J and Lifshitz F: Development of the neonatal rat small intestinal barrier to non-specific macromolecular absorption. Role of dietary corticosterone. Pediatr Res 32: 50-57, 1992.

37. Rumbo M and Schiffrin EJ: Ontogeny of intestinal epithelium immune functions: developmental and environmental regulation. Cell Mol Life Sci 62: 1288-1296, 2005.

38. Smyth SH, Feldhaus S, Schumacher U and Carr KE: Uptake of inert microparticles in normal and immune deficient mice. Int J Pharm 346: 109-118, 2008.

39. Israel EJ, Patel VK, Taylor SF, Marshak-Rothstein A and Simister NE: Requirement for a beta 2-microglobulin-associated $\mathrm{Fc}$ receptor for acquisition of maternal IgG by fetal and neonatal mice. J Immunol 154: 6246-6251, 1995.

40. Roopenian DC and Akilesh S: FcRn: the neonatal Fc receptor comes of age. Nat Rev Immunol 7: 715-725, 2007.

41. Kramer DR and Cebra JJ: Early appearance of 'natural' mucosal IgA responses and germinal centers in suckling mice developing in the absence of maternal antibodies. J Immunol 154: 2051-2062, 1995.

42. Johnson CJ, Pedersen JA, Chappell RJ, McKenzie D and Aiken JM: Oral transmissibility of prion disease is enhanced by binding to soil paticles. PLoS Pathog 3: e93, 2007. 